Teodora Tica*

University of Novi Sad, Faculty of Economics, Subotica, Serbia and Ernst \& Young doo, Belgrade, Serbia

\title{
The Impact of Corporate Income Tax on Capital Structure: Evidence from Serbian Food Industry
}

DOI: 10.7595/management.fon.2021.0030

\begin{abstract}
:
Research Question: The aim of this paper is to present the effect of corporate income tax on capital structure in the food industry of the Republic of Serbia. Motivation: Based on the empirical results of Moradi \& Paulet (2018) and Kuc \& Kalicanin (2021), the author's aim of the research conducted in this paper is to analyse the impact of corporate income tax on the capital structure in the Republic of Serbia as a developing country with an underdeveloped capital market and to support the results of this sporadically researched area of corporate finance in the Republic of Serbia. Idea: The author believes that by determining the optimal capital structure, it could be possible to reduce the burden of corporate income tax. Given that the food industry is one of the most significant and profitable industries in the Republic of Serbia, the results of this theoretical and empirical research would be of a great benefit to the local Tax Authority and to large taxpayers. Data: The research was conducted on a sample of 250 most active companies that operated within the food industry of the Republic of Serbia in the period from 2017 to 2019. The source of data for the purposes of this research are the official financial reports of companies registered with the Serbian Business Registers Agency. Tools: Elemental descriptive statistics techniques and panel regression analysis were applied throughout the data analysis. For the purpose of data processing the author used STATA statistical software. Findings: The results confirmed the existence of a negative and statistically significant relationship between tax savings based on depreciation costs and profitability on the one hand, and capital structure, on the other. Thus, the results indicate the need of profitable companies to use high depreciation costs to provide a reduced burden of corporate income tax with a capital structure shifted to accumulated own financial resources. In addition, the results of the regression model showed the absence of a statistically significant effect of tax savings based on interest costs on capital structure. Contribution: The contribution of this paper is reflected in additional support to existing discussions on impact of corporate income taxes on capital structure. Further, the paper contributes to business practice by determining how corporate income tax burden could be reduced by choosing optimal financial mix.
\end{abstract}

Keywords: capital structure, corporate income tax, food industry

JEL Classification: C20, C30, G30, L60, M20

\section{Introduction}

The study of the optimal capital structure and financial mix is a never sufficiently researched topic in the field of corporate finance, which has been the subject of numerous studies by many authors for several decades. The answer to the key question of the optimal proportion between own and borrowed sources is examined by the top management of each company, considering the advantages and disadvantages of internal versus external sources of financing. The main advantage of the capital structure shifted to borrowed resources is related to the tax savings based on the deduction of interest costs, as opposed to the costs of dividends. In addition, it is believed that predominantly indebted companies lead to greater management discipline, since the existence of an obligation to repay borrowed money is leaving small amount of available cash flows for reckless investment.

On the other hand, such capital structure creates certain risks. Among them, the main risk refers to the inability to settle obligations to the lender, as well as the risk of bankruptcy. With further borrowing, each 
company loses flexibility regarding future external financing, i.e., lowers its credit rating, causing an increase in financing costs and worsening credit conditions. Damodaran (2007) believes that any additional borrowing can evoke conflicts between the lender and the owner or shareholder.

Furthermore, two research directions have been considered in the literature so far. One group of authors believes that the benefits of borrowing are ultimately offset by interest costs, while another group of authors argues that the benefits of borrowing manifest only to a certain level.

The purpose of the research conducted in this paper is the assessment of the impact of corporate income tax depending on interest costs and depreciation costs on the capital structure, as well as the assessment of the effects of other determinants of capital structure such as company size, asset tangibility, liquidity and profitability.

The aim of the research is to theoretically and empirically present the effects of capital structure factors, primarily between tax savings and the proportion of borrowed and own financial sources of companies operating within food industry of the Republic of Serbia in the period from 2017 to 2019.

The paper is presented through three related sections. The first section presents an overview of research results and conclusions of other authors regarding the influence of capital structure determinants on the proportion of internal and external sources of financing. The second part of the paper presents the composition of the sample, data source, overview of the variables used, as well as a description of the conducted research methodology. The third segment of the paper presents the results of the empirical section of the study, explanations and conclusions based on the evaluation of the regression model.

\section{Literature Review}

By comparing the results of research works conducted in the last few decades regarding the influence of different determinants of capital structure, the presence of inconsistencies between the authors can be noticed. The main difference in conclusions refers to the discrepancy between the direction of the influence of a particular determinant on the capital structure, as well as in its statistical significance. Below are presented the views of individual authors on the extent to which corporate income tax, profitability, size, liquidity and asset structure of companies affect changes in the capital structure.

The capital structure reflects the way in which companies' funds are financed, showing the relative share of debts in total sources of financing. From the economic aspect, it is completely expected that every company does not finance the improvement and the growth of its business from exclusively accumulated own funds. Consequently, companies often rely on external financing opportunities, which together with their own funds form capital structure. According to the research of Petkovic et al. (2019), conducted on the example of companies from the Republic of Serbia, local companies mainly use internal funds, while external sources of financing are used to a lesser extent. The capital structure is a good indicator of a company's risk, given that companies with a higher share of debt in total sources are being considered as less flexible and much riskier (Wahab \& Ramli, 2014). In addition, research conducted by Kuc \& Kalicanin (2021) shows that large Serbian companies have a low share of long-term debt and a very high share of short-term debt.

There are several criteria and factors to be considered when choosing an appropriate financing source. The most common problem in this process is an existing contradiction between the determinants of the capital structure, which makes the choice itself extremely complex.

Subsequently after Miller \& Modigliani (1963), had introduced additional changes to the former theory of capital structure by introducing a tax category, corporate income tax became of great influence on decisions on capital structure. One of the most influential proposition of amended M\&M theory states that the greatest benefit from tax savings that is realized on the basis of tax deduction of interest cost is the increased value of the company. Therefore, it leads to a situation in which a company is considered more valuable if it is more indebted. Confirmation of this fact is precisely in the deduction of interest costs, which affects the reduction of the tax base in the tax balance, and thus also the liability for corporate income tax and cash outflows. Given that the amount of collected and spent cash is considered when determining the value of the company, it was concluded that the deduction of interest expense is a factor of great importance. In the decades following the theory, corporate income tax became one of the main subjects of research in the field of corporate finance.

In addition to the theoretical development of this topic, in recent years, tax authorities have been developing tax policies related to corporate income. The tax administrations of countries around the world have prescribed a set of costs whose deduction in the tax balance can reduce the amount of taxable profit, such 
as interest costs. Consequently, the capital structure directed mainly towards borrowed resources is an attractive choice for companies with high taxable profits.

Considering results of local research, it is necessary to refer to one of the latest analysis of this topic conducted by Kuc \& Kalicanin (2021). They investigate determinants of capital structure of the top 141 largest Serbian non-financial companies in the period following the global economic crisis in 2008. This study shows that effective tax rate measured by dividing tax expense for the period by profit before taxes, have no significant impact on capital structure of the largest companies in the Republic of Serbia. Furthermore, Vrzina (2019) investigates whether the Serbian companies listed on the Belgrade Stock Exchange have enhanced borrowing external funds after the increase of the prescribed corporate income tax rate in 2013. The author states that despite an increase in prescribed corporate income tax rates, companies in the Republic of Serbia have not boosted their debt levels. Withal, Vrzina considers a limited availability of borrowing funds, high interested rates on bank loans, low corporate income tax burden and availability of non-debt tax shields as a substitute for tax savings are the main causes of such behaviour of taxpayers in the Republic of Serbia. On the other hand, Arsov (2016) analyzed the capital structure of the Serbian joint-stock companies, most frequently traded on the Belgrade Stock Exchange and concluded that average effective tax rates of companies have a significant and negative impact on capital structure.

As far as foreign research is concerned, Bauer (2004) and Thalib et al. (2019) argue the existence of a positive relationship between tax savings based on interest expenses deductibility and capital structure. On the other hand, Pirtea et al. (2014) concluded, after analyzing the capital structure of Romanian companies, that there is a significant negative impact of tax rate, determined by dividing taxes paid by taxable income, to capital structure. Moradi \& Paulet (2018) carried out a large sample survey of 559 companies operating within six developed European countries. The authors conducted the research from several aspects primarily from the aspect of different states. Secondly, from the aspect of different industries, as well as from the time aspect as regards the Euro crisis. In the end, they have concluded that tax shields are significantly negatively related to the capital structure. Some authors such as Nasution et al. (2017) consider that there is no statistically significant influence between tax shields and debt to total assets ratio. Although many authors have measured tax shield effect as ratio of current tax expense and net income, in this paper, effective tax rate is determined as a ratio of total tax expenses, including either current or deferred taxes, and EBIT or better known as operating income in Serbian profit and loss statement. The reasons for this selection of measurement are twofold. Firstly, the use of deferred taxes in addition to the current tax expense more accurately shows the effect of tax burden on the financial result of companies in one financial year. Secondly, the use of operating profit instead of net profit provides a more precise estimate of business operations and level of activity, especially within a sample of manufacturing and non-financial corporations.

According to the Serbian Corporate Income Tax Law, many prescribed expenses are considered as deductible when compiling the annual tax balance. Besides interest costs, asset depreciation costs are one of these.

The negative relationship between the share of depreciation cost in total assets, on the one hand, and capital structure, on the other hand, is known as non-debt tax shields, which shows the taxpayer's intention to reduce the amount of taxable profit by incurring high depreciation costs. One of the most common ways to generate the increase in depreciation costs could be by determining the shorter life of fixed assets by accounting policies, or by increasing depreciation rates. Accordingly, taxpayers will be able to use tax savings without directing the capital structure more towards borrowed resources. In this regard, the negative relationship was stipulated by DeAngelo et al. (1980), Bauer (2004), Deesomsak (2004) and Nasution et al. (2017).

Notwithstanding the above, some authors share the opposite view. Bradley et al. (1984) believe that companies that have a high value of fixed assets and intangible assets create an adequate collateral and more favourable credit conditions when borrowing. Particularly, Delcoure (2007), Bajramovic (2017) and Moradi \& Paulet (2018) believe that there is a positive relationship between the non-debt tax shields effect and the capital structure.

Kakilli Acaravici (2015), Singh (2016), Pepur et al. (2016) and Thalib et al. (2019) consider that the tax savings in this form are not a statistically significant category when analyzing the capital structure.

Company size is one of the most commonly used variables when analyzing capital structure (Singh, 2016). The size of a company is a characteristic of legal entities that is closely related to the borrowing amount of the companies. Since large companies have a high level of fixed assets, such companies usually have a greater ability to borrow and better creditworthiness with financial institutions. On the other hand, according to Dogan (2013), the size of the company has a positive effect on profitability. Consequently, large companies 
are usually able to finance themselves from retained earnings of the current or previous years. Wahab \& Ramli (2014), Kakilli Acaravci (2015), Guner (2016), as well as Bajramovic (2017) have agreed with the previous fact on the existence of a negative relationship between the size and the structure of capital in the last decade.

When making decisions about capital structure, profitability plays an important role. Results derived from Stancic et al. (2016) research about testing relevance of alternative capital structure theories in Serbian economy based on 674 production-oriented observations and 588 service- oriented observation show that the level of leverage increases with the decrease in profitability. According to Singh (2016), profitability leads to the creation of retained earnings and available reserves, thus it reduces the need for additional borrowing in the capital market. This attitude about the negative relationship between profitability and capital structure was confirmed by Malinic et al. (2013), Kakilli Acaravci (2015), Guner (2016), Nasution et al. (2017), as well as Thalib et al. (2019).

According to Harc (2014), companies are mainly financed according to the maturity of debts, i.e., there is a positive relationship between fixed tangible assets and long-term debts, while the relationship between fixed tangible assets and short-term debts is negative. The positive relationship between the asset structure and the capital structure was confirmed by the studies of Wahab \& Ramli (2014), Bajramovic (2017), Moradi \& Paulet (2018), Oktavina et al. (2018), Buana \& Khafid (2018) and Harc (2019).

Unlike them, when it comes to the negative impact of tangibility, Stancic et al. (2016) state that the level of leverage increases with the decrease in share of fixed assets in total assets. The other group of authors, among them Malinic et al. (2013), Koralun-Bereznicka (2013), Kakilli Acaravci (2015), Arsov \& Naumoski (2016), agree that there exists a negative relationship between the tangibility and capital structure. In this particular case, Malinic et al. (2013) point to the inflexibility of the Serbian capital market and the lack of different sources of financing.

Additionally, Deari \& Deari (2009), Singh (2016), Ariyani et al. (2018), Silwal (2019) did not realize a statistically significant relationship between asset structure and capital structure.

There are known views in the literature regarding the impact of liquidity on the capital structure. Malinic et al. (2013), Wahab \& Ramli (2014), Singh (2016) and Guner (2016) concluded through research that highly liquid companies have no need for additional borrowing.

Based on the aim of this research, as well as on the theoretical framework, the hypotheses that will be tested within the paper are the following:

$\mathrm{H} 1$ : There is a statistically significant relationship between the tax shield effect and the capital structure of companies within the food industry in the Republic of Serbia.

H2: There is a statistically significant relationship between the non-debt tax shield effect without debts and the capital structure of companies within the food industry in the Republic of Serbia.

\section{Empirical Data and Methodology}

The subject of the research presented in the paper is the impact of corporate income tax on the capital structure of companies in the food industry of the Republic of Serbia in the period from 2017 to 2019. Accordingly, the conducted research assesses the direction and strength of the influence of capital structure determinants, primarily corporate income tax. In addition, the paper includes an assessment of the impact of company size, liquidity, asset structure and profitability on the financial mix.

The data source includes the official financial reports of companies registered with the Business Registers Agency of the Republic of Serbia with activity codes within sector C, area 10 - Food production, according to the Regulation on Classification of Activities (Official Gazette RS, 2010). The sample included top 250 active companies with the highest amount of operating income in 2019 within the food industry of the Republic of Serbia. In that manner, it is ensured that the sample includes the companies with the highest level of operations, regardless of the fact that some of them operated at a loss. Thus, the results of the analysis were driven by the largest and most active representatives of this industry. Considering that TP Catalyst software, developed by Bureau van Dijk, was used for the formation of the sample, companies that did not provide financial data to TP Catalyst for the entire analyzed period were excluded from the sample. 
In addition, it should be noted that the food industry was taken into account primarily due to its largest contribution to the GDP of the Republic of Serbia, which accounted for up to $13.7 \%$ in 2019, according to the latest data (Republicki zavod za statistiku (Statistical Office of the Republic of Serbia), 2020).

The selection of dependent and independent variables is based on the theoretical framework. The following table shows the variables used in evaluating the model in this paper, together with the literature source.

Table 1: A review of theoretical framework for dependent and independent variables

\begin{tabular}{|c|c|c|c|c|}
\hline $\begin{array}{l}\text { Variable } \\
\text { category }\end{array}$ & $\begin{array}{c}\text { Variable } \\
\text { name }\end{array}$ & Abbreviation & Variable formulation & Literature source \\
\hline $\begin{array}{l}\text { Dependent } \\
\text { variable }\end{array}$ & $\begin{array}{l}\text { Capital } \\
\text { Structure }\end{array}$ & CS & Total debt / Total assets & $\begin{array}{l}\text { Delcoure (2007), Malinic et al. (2013), } \\
\text { Wahab \& Ramli (2014), Singh (2016), } \\
\text { Pepur et al. (2016), Guner (2016), } \\
\text { Bajramovic (2017), Vrzina (2019). }\end{array}$ \\
\hline \multirow{6}{*}{$\begin{array}{l}\text { Independen } \\
\text { t variables }\end{array}$} & $\begin{array}{l}\text { Tax shield } \\
\text { effect }\end{array}$ & TS & $\begin{array}{l}\text { Total corporate income } \\
\text { tax expense (including } \\
\text { current and deferred } \\
\text { expense) / EBIT }\end{array}$ & $\begin{array}{l}\text { Negash (2002), Vatavu (2015), Thalib et } \\
\text { al. (2019). }\end{array}$ \\
\hline & $\begin{array}{l}\text { Non-debt } \\
\text { tax shield } \\
\text { effect }\end{array}$ & NDTS & $\begin{array}{l}\text { Depreciation expense / } \\
\text { Total assets }\end{array}$ & $\begin{array}{l}\text { Bajramovic (2017), Bauer (2004), } \\
\text { Delcoure (2007), Deari \& Deari (2009), } \\
\text { Pirtea et al. (2014), Kakilli Acaravci } \\
\text { (2015), Guner (2016), Pepur et al. } \\
\text { (2016), Nasution et al. (2017), Moradi \& } \\
\text { Paulet (2018). }\end{array}$ \\
\hline & $\begin{array}{l}\text { Asset } \\
\text { Structure }\end{array}$ & AS & $\begin{array}{l}\text { Fixed assets / Total } \\
\text { assets }\end{array}$ & $\begin{array}{l}\text { Delcoure (2007), Deari \& Deari (2009), } \\
\text { Malinic et al. (2013), Wahab \& Ramli } \\
\text { (2014), Saleh et al. (2015), Kakilli } \\
\text { Acaravci (2015), Vatavu (2015), Singh } \\
\text { (2016), Stancic et al. (2016), Pepur et al. } \\
\text { (2016), Arsov \& Neumoski (2016), } \\
\text { Pepur et al. (2016), Setiadharma \& } \\
\text { Machali (2017), Bajramovic (2017), } \\
\text { Buana \& Khafid (2018), Moradi \& Paulet } \\
\text { (2018), Harc (2019). }\end{array}$ \\
\hline & Size & SIZE & Ln Total assets & $\begin{array}{l}\text { Delcoure (2007), Deari \& Deari (2009), } \\
\text { Wahab \& Ramli (2014), Pepur et al. } \\
\text { (2016), Kakilli Acaravci (2015), Singh } \\
\text { (2016), Stancic et al. (2016), Pepur et al. } \\
\text { (2016), Guner (2016), Arsov \& } \\
\text { Neumoski (2016), Bajramovic (2017), } \\
\text { Moradi \& Paulet (2018), Ariyani et al. } \\
\text { (2018), Silwal (2019). }\end{array}$ \\
\hline & Liquidity & LIQ & $\begin{array}{l}\text { Current assets / Current } \\
\text { liabilities }\end{array}$ & $\begin{array}{l}\text { Malinic et al. (2013), Wahab \& Ramli } \\
\text { (2014), Vatavu (2015), Pepur et al. } \\
\text { (2016), Singh (2016), Stancic et al. } \\
\text { (2016), Guner (2016), Stevanovic et al. } \\
\text { (2019). }\end{array}$ \\
\hline & Profitability & PROFIT & ROA & $\begin{array}{l}\text { Delcoure (2007), Deari \& Deari (2009), } \\
\text { Malinic et al. (2013), Wahab \& Ramli } \\
\text { (2014), Vatavu (2015), Kakilli Acaravci } \\
\text { (2015), Pepur et al. (2016), Stancic et al. } \\
\text { (2016), Guner (2016), Bajramovic } \\
\text { (2017), Nasution et al. (2017), Moradi \& } \\
\text { Paulet (2018), Oktavina et al. (2018), } \\
\text { Ariyani et al. (2018), Silwal (2019), } \\
\text { Thalib et al. (2019), Stevanovic et al. } \\
\text { (2019). }\end{array}$ \\
\hline
\end{tabular}




\section{Results and Discussion}

Descriptive statistics of variables are presented in the following table. The table shows the arithmetic mean, standard deviation, as well as the minimum and maximum value of selected variables for 750 observations in a sample of 250 companies in the food industry of the Republic of Serbia.

Table 2: Results of descriptive statistics

\begin{tabular}{|l|c|c|c|c|c|}
\hline \multicolumn{1}{|c|}{ Variable } & Observation & Mean & $\begin{array}{c}\text { Standard } \\
\text { Deviation }\end{array}$ & Minimum & Maximum \\
\hline $\begin{array}{l}\text { Capital } \\
\text { Structure }\end{array}$ & 750 & 0.309 & 0.218 & 0.000 & 1.230 \\
\hline Tax shield & 750 & 0.077 & 0.738 & -17.561 & 6.181 \\
\hline $\begin{array}{l}\text { Non-debt tax } \\
\text { shield }\end{array}$ & 750 & 0.030 & 0.020 & 0.000 & 0.225 \\
\hline Size & 750 & 8.945 & 1.254 & 5.935 & 13.105 \\
\hline Profitability & 750 & 4.733 & 6.997 & -50.565 & 37.221 \\
\hline Asset Structure & 750 & 0.449 & 0.184 & 0.001 & 0.9470 \\
\hline Liquidity & 750 & 1.970 & 2.841 & 0.209 & 56.862 \\
\hline
\end{tabular}

Source: Authors' calculations

The results of the descriptive statistical analysis show that, on average, companies are mostly financed from their own sources. Additionally, the asset structure of entities from the sample is balanced. Hence, it can be interpreted that companies from the sample, on average, have an enviable guarantee substance for creditors on the financial market, in the form of a high value of long-term assets. In general, companies from Serbian food industry are highly profitable and liquid. Accordingly, it can be assumed that due to high profitability, companies are financed from current or retained earnings in previous years.

At the beginning of the panel regression analysis, a regression model was determined in accordance with the previously formulated hypotheses and variables. The regression equation is shown below:

$$
\text { CSit }=\beta 0+\beta 1 \text { TSit }+\beta 2 \text { NDTSit }+\beta 3 \text { SIZEit }+\beta 4 \text { PROFITit }+\beta 5 \text { ASit }+\beta 6 \text { LIQit }+\varepsilon i t
$$

Hausman's test was used to detect more appropriate specification of the model. The result of the test showed that the fixed effects model was adequate.

Table 3: Results of evaluation of a regression model with a fixed specification

\begin{tabular}{|l|c|c|c|c|}
\hline \multicolumn{1}{|c|}{ Capital Structure } & Coefficient & Standard Error & t-Statistic & $\mathbf{P}>\mathbf{~ t ~ |}$ \\
\hline Tax shield & 0.004 & 0.005 & 0.77 & 0.442 \\
Non-debt tax shield & -1.358 & 0.527 & -2.57 & 0.010 \\
Size & 0.020 & 0.022 & 0.91 & 0.363 \\
Profitability & -0.006 & 0.001 & -7.96 & 0.000 \\
Asset Structure & 0.012 & 0.061 & 0.20 & 0.842 \\
Liquidity & -0.003 & 0.002 & -1.53 & 0.126 \\
& & & & \\
R-squared & 0.1335 & & & \\
Adjusted R-squared & 0.1265 & & & \\
F-Statistic & $12.91(p=0.000)$ & & & \\
\hline
\end{tabular}

Source: Authors' calculations

Furthermore, it is necessary to test the existence of autocorrelation, as the basic assumptions of regression analysis. Autocorrelation is considered to be a form of connection between the values of the time series in different time periods of observation. The Wooldridge test is applied for detecting the presence of autocorrelation in the regression model. Since the obtained value $p=0.1610>0.05$, the null hypothesis is confirmed and the absence of autocorrelation is determined. The results of the Wooldridge test are presented in the table below. 
Table 4: The Wooldridge test results

\begin{tabular}{|l|c|}
\hline \multicolumn{2}{|c|}{$\mathbf{H}_{\mathbf{0}}$ : no first-order autocorrelation } \\
\hline F-Statistic & 1.977 \\
\hline P-value & 0.1610 \\
\hline
\end{tabular}

Source: Authors' calculations

The results of regression analysis show that the debt driven determinant of capital structure such as corporate income tax based on interest costs is not statistically significant when considering its effect on capital structure. In this regard, hypotheses $\mathrm{H} 1$ is rejected. In this regard, the results of Kuc \& Kalicanin (2021) and Vrzina (2019) about the impact of tax shield on capital structure are confirmed. Therefore, it can be concluded that the most active companies in the Serbian food industry do not consider the tax rate when making a decision on the capital structure, i.e., the amount of additional borrowing. As far as foreign research is concerned, the results of the analysis are in accordance with the conclusion reached by Nasution et al. (2017), who consider that there is no statistically significant influence between tax shields and debt to total assets ratio.

Further, since the estimated value $p=0.010<0.05$ for the second regression coefficient regarding non-tax shield is lower than the significance threshold, hypothesis $\mathrm{H} 2$ is accepted and confirms the existence of a negative and statistically significant relationship between corporate income tax based on depreciation costs and capital structure. The negative relationship was stipulated by the authors DeAngelo et al. (1980), Bauer (2004), Deesomsak (2004) and Nasution et al. (2017). In this particular case, the research conducted in this paper showed that the conclusions reached by the aforementioned authors also apply to companies operating in the food industry, one of the largest industries in the Republic of Serbia. In this manner, it is noticeable that Serbian taxpayers take into account only non-debt shield when considering the debt-toequity ratio of the company.

Conclusion

The food industry of the Republic of Serbia is one of the most important sectors of the domestic economy, making a large part of domestic exports. Doing business in highly competitive areas of the economy requires careful decision-making on all segments of operations, both internal and external. One of the most vital decisions that needs to be made by top management is the decision on the capital structure. What precedes such a decision is taking into consideration all the factors that influence the proportion of borrowed and own financial sources. The aim of the research presented in this paper is to assess the effect of corporate income tax, as well as the tangibility, company size, profitability and liquidity on the capital structure of companies in the food industry of the Republic of Serbia. The results of the panel regression analysis showed that there is a negative and statistically significant impact of non-debt tax shield on the capital structure. In other words, companies use the right to deduct the costs of asset depreciation. In that manner, companies compensate the tax savings that would be obtained on the basis of interest costs by additional borrowing in a capital market. In this way, companies that perform business activities within the food industry are capable of bearing a lower burden of corporate income tax and have their capital structure turned more towards their own resources. Considering the results of the research, it can be concluded that the entities in the sample take tax planning into account when it comes to this form of tax. Further, the results of the regression model assessment also included the impact of the tax shield based on interest expenses deductibility. However, the research detected the absence of statistical significance of the mentioned capital structure determinant in the food industry of the Republic of Serbia. Considering that the Republic of Serbia is a country with one of the lowest corporate income tax rates in Europe, it was expected that the effective tax rate is not an important factor when deciding on the capital structure, what was confirmed by the results of the research. These results are in line with the conclusions of the Kuc \& Kalicanin (2021), Vrzina (2019) and Nasution et al. (2017). Additionally, Serbian corporate income tax rate is lower than the rates that were in force at the time of the emergence of the M\&M theory. Taking into account the insufficiently developed capital market in the Republic of Serbia and a low corporate income tax rate, reduced interest of companies in additional borrowing in order to achieve tax savings could be expected.

Despite the wide range of research on the determinants of capital structures and on the validation of previously established theories of capital structure, the impact of corporate income tax on debt-to-assets ratio is not clear enough. The main reason is that the largest number of theories of capital structure originated in developed countries with developed capital market and high corporate income tax rates. Therefore, the significance of this paper is that this topic has been partially covered based on a sample of companies from the Republic of Serbia, especially of companies that participate in one of the most successful and competitive manufacturing industries, such as food industry. Additionally, the results obtained in this research will most likely be competitive to other production branches of the industry of the Republic of Serbia. Also, 
the importance of this paper is reflected in the fact that companies operate within a country in transition which is a candidate for EU membership. The paper results contribute to the literature and business practice by determining how corporate income tax burden could be reduced by choosing an optimal financial mix.

The study conducted in this paper has several limitations. These refer primarily to the fact that the research was conducted on the basis of companies from one industry within the Republic of Serbia. In this regard, it is not possible to fully apply the obtained results to another industry without considering the main characteristics of food industry and its market. A further restriction refers to the fact that the most successful companies in the food industry, i.e., the companies with the highest amount of operating revenue, are included in the analysis. Therefore, the analysis did not cover companies with lower level of operation in 2019. In addition, the analysis is conducted using one dependent variable, taking into consideration only the ratio of total debt and total assets as capital structure proxy. The author opted for this ratio because of its most common use, which enables the comparison of results with previously conducted research. Therefore, the impact of corporate income tax on the ratio of long-term debt or short-term debt to total assets or to equity has not been analyzed in more details. Also, empirical research was carried out with data that were not affected by the COVID-19 pandemic. The future research could focus on the effect of the pandemic, given that it was challenging to maintain the planned optimal capital structure and planned performance of the companies in all sectors in the Republic of Serbia.

\section{REFERENCES}

[1] Ariyani, H. F., Pangestuti, I. R. D., \& Raharjo, S. T. (2018). The effect of asset structure, profitability, company size, and company growth on capital structure (The Study of Manufacturing Companies Listed on the IDX for the Period 2013-2017). Jurnal Bisnis Strategi, 27(2), 123-136. DOI: 10.14710/jbs.27.2.123-136

[2] Arsov, S. (2016). Capital Structure in Emerging Markets: The Case of Serbian Joint-Stock ompanies. Economic Analysis, 49, 1-2. Retrieved from: https://www.library.ien.bg.ac.rs/index.php/ea/article/view/324/320

[3] Arsov, S., \& Naumoski, A. (2016). Determinants of capital structure: An empirical study of companies from selected post-transition economies. Zbornik radova Ekonomskog fakulteta Rijeka, 34(1), 119-146. DOI: 10.18045/zbefri.2016.1.119

[4] Bajramovic, A. (2017). Firm-Specific Determinants of Capital Structure - Case of firms in Bosnia and Herzegovina. Advanced in Business-Related Scientific Research Journal, 8(2), 13-24. Retrieved from: http://www.absrc.org/wp-content/uploads/2017/12/PAPER-Bajramovic.pdf

[5] Bauer, P. (2004). Determinants of capital structure: empirical evidence from the Czech Republic. Czech Journal of Economics and Finance, 54(1-2), 2-21. Retrieved from: http://journal.fsv.cuni.cz/storage/958_s_2-21.pdf

[6] Bradley, M., Jarrell, G. M., \& Kim, E. H. (1984). On the Existence of an Optimal Capital Structure: Theory and Evidence. Journal of Finance, 56, 857-878. DOI: 10.1111/j.1540-6261.1984.tb03680.x

[7] Buana, F., \& Khafid, M. (2018). The Effect of Asset Structure and Business Risk on Capital Structure with Profitability as the Moderating Variable. Accounting Analysis Journal, 7(3), 200-206. DOI: 10.15294/aaj.v7i3.22727

[8] Damodaran, A. (2007). Korporativne finansije, teorija i praksa. Modus - Centar za statisticka istrazivanja i prognoze.

[9] Deari, M., \& Deari, F. (2009). The determinants of capital structure: Evidence from Macedonian listed and unlisted companies. Analele Stiintifice ale Universitatii "Alexandru loan Cuza" din lasi - Stiinte Economice (1954-2015), Alexandru loan Cuza University, Faculty of Economics and Business Administration, 56, 91102. Retrieved from: http://anale.feaa.uaic.ro/anale/resurse/08 F04_Deari.pdf

[10] DeAngelo, H., \& Masulis, R. (1980). Optimal capital structure under corporate and personal taxation, Journal of Financial Economics, 8, 3-29. DOI:10.1016/0304-405X(80)90019-7

[11] Deesomsak, R., Paudyal, K, \& Pescetto, G. (2004). The determinants of Capital Structure: Evidence from the Asia Pacific region. Journal of Multinational Financial Management, 14(4), 387-405. DOI: 10.1016/j.mulfin.2004.03.001

[12] Delcoure, N. (2007). The Determinants of capital structure in transitional economies. International Review of Economics and Finance, 16(3), 400-415. DOI: 10.1016/j.iref.2005.03.005

[13] Dogan, M. (2013). Does Firm Size Affect the Firm Profitability? Evidence from Turkey. Research Journal of Finance and Accounting, 4(4), 53-59. Retrieved from: https://www.researchgate.net/publication/305222472_Does_Firm_Size_Affect_The_Firm_Profitability_ Evidence from Turkey

[14] Guner, A. (2016). The Determinants of Capital Structure Decisions: New Evidence from Turkish Companies. Procedia Economics and Finance, 38, 84-89. DOI: 10.1016/S2212-5671(16)30180-0

[15] Harc, M. (2015). The Relationship between Tangible Assets and Capital Structure of small and mediumsized companies in Croatia. Ekonomski Vjesnik, Broj 1/2015, 213-224. Retrieved from: https://hrcak.srce.hr/ojs/index.php/ekonomski-vjesnik/article/view/3138 
[16] Harc, M. (2019). Struktura kapitala malih i srednjih poduzeca u Republici Hrvatskoj. Poslovna izvrsnost, 13(1), 87-101. Retrieved from: https://hrcak.srce.hr/221255

[17] Kakilli Acaravci, S. (2015). The Determinants of Capital Structure: Evidence from the Turkish Manufacturing Sector. International Journal of Economics and Financial Issues, 5(1), 158-171. Retrieved from: http://www.econjournals.com/index.php/ijefi/article/view/1039

[18] Koralun-Bereznicka, J. (2013), How Does Asset Structure Correlate with Capital Structure? - CrossIndustry and Cross-Size Analysis of the EU Countries. Universal Journal of Accounting and Finance, 1(1), 19-28. DOI: 10.13189/ujaf.2013.010103

[19] Kuc, M., \& Kalicanin, D. (2021). Determinants of the capital structure of large companies: Evidence from Serbia. Economic research-Ekonomska Istrazivanja, 34:1, 590-607, DOI: 10.1080/1331677X.2020.1801484

[20] Malinic, D., Dencic-Mihajlov, K., \& Ljubenovic, E. (2013). The Determinants of Capital Structure in Emerging Capital Markets: Evidence from Serbia. European Research Studies, 16(2), 98-119. DOI: 10.35808/ersj/391

[21] Modigliani, F., \& Miller, M. (1963), Corporate income taxes and the cost of capital: a correction. American

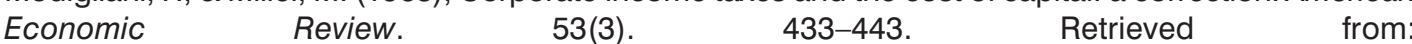
https://www.jstor.org/stable/1809167?origin=JSTOR-pdf

[22] Moradi, A., \& Paulet, E. (2018), The Firm-specific Determinants of Capital Structure - An Empirical Analysis of Firms before and during the Euro Crisis, Research in International Business and Finance. 47, 150-161. DOI: 10.1016/j.ribaf.2018.07.007

[23] Nasution, A. A., Siregar, I., \& Panggabean, R. (2017). The Effect of Profitability, Asset Tangibility, Corporate Tax, Non-debt Tax Shield and Inflation upon the Financial Capital Structure of the Manufacturing Companies listed on the Indonesian Stock Exchange. Advances in Economics, Business and Management Research, 36, 65-74. DOI: 10.2991/icbmr-17.2017.6

[24] Negash, M. (2002). Corporate tax and capital structure: some evidence and implications. Investment Analysts Journal, 31(56), 17-27, DOI: https://doi.org/10.1080/10293523.2002.11082439

[25] Oktavina, M., Manalu, S., \& Yuniarti, S. (2018). Pecking Order and Trade-off Theory in Capital Structure Analysis of Family Firms in Indonesia. Jurnal Keuangan dan Perbankan, 22(1), 73-82. DOI: 10.26905/jkdp.v22i1.1793

[26] Pepur, S., Curak, M., \& Poposki, K. (2016). Corporate capital structure: the case of largest Croatian companies. Economic Research - Ekonomska Istrazivanja, 29(1), 498-514. Retrieved from: https://hrcak.srce.hr/171738

[27] Petkovic, G., Konjikusic, S., Barjaktarovic, L., \& Pindzo R. (2019). What is the Real State of Financial Management in Companies in the Republic of Serbia? Management: Journal of Sustainable Business and Management Solutions in Emerging Economies, 24(2), 23-34. DOI: 10.7595/management.fon.2018.0002

[28] Pirtea, M., Nicolescu A., C., \& Botoc, C. (2014). Do Romanian companies follow Pecking Order financing? Economic computation and economic cybernetics studies and research/Academy of Economic Studies. 48(1). Retrieved from: https://www.researchgate.net/publication/287301222_Do_Romanian_companies_follow_Pecking_Order financing

[29] Republicki zavod za statistiku (2020). Bruto domaci proizvod, 2019. Statistika nacionalnih racuna. 269. Retrieved from: https://publikacije.stat.gov.rs/G2020/Pdf/G20201269.pdf

[30] Saleh, H., Priyawan, S., \& Ratnawati, T. (2015). The Influence of Assets Structure, Capital Structure and Market Risk on the Growth, Profitability and Corporate Values (study In Manufacturing Companies Listed in Indonesia Stock Exchange. International Journal of Business and Management Invention, 4(12), 4553. Retrieved from: http://www.ijbmi.org/papers/Vol(4)12/F04012045053.pdf

[31] Setiadharma, S., \& Machali, M. (2017). The Effect of Asset Structure and Firm Size on Firm Value with Capital Structure as Intervening Variable. Journal of Business \& Financial Affairs, 6(4), 1-5. DOI: 10.4172/2167-0234.1000298

[32] Silwal, P. (2019). Asset liquidity and capital structure: Empirical evidence from Nepal, SEBON Journal, VII May, 108-119. Retrieved from: https://www.researchgate.net/profile/BharatDhungana/publication/348050439 Role of Financial Institutions in Economic Growth A Case of Ne $\mathrm{pal} /$ links/5fede830a6fdccdcb81 e785f/Röle-of-Financial-Institutions-in-Economic-Growth-A-A-Case-ofNepal.pdf

[33] Singh, D. (2016). A Panel Data Analysis of Capital Structure Determinants: An Empirical Study of NonFinancial Firms in Oman. International Journal of Economics and Financial Issues, 6(4), 1650-1656. Retrieved from: https://www.econjournals.com/index.php/ijefi/article/view/2998/pdf

[34] Stancic, P., Jankovic, M., \& Cupic, M. (2016). Testing the relevance of alternative capital structure theories in Serbian economy. Teme, 4, 1309-1325. Retrieved from: http://teme2.junis.ni.ac.rs/index.php/TEME/article/view/277 
[35] Stevanovic, S., Minovic, J., \& Ljumovic, I. (2019). Liquidity Profitability Trade-off: Evidence from Medium Enterprises. Management: Journal of Sustainable Business and Management Solutions in Emerging Economies, 24(3), 71-77. DOI: 10.7595/management.fon.2019.0004

[36] Thalib, F., Herdiyana, H., \& Wahid, A. (2019). Tax and not Tax on Capital Structure of Real Estate and Property Company. International Journal of Economics and Financial Issues, 9(2), 87-95. Retrieved from: https://www.econjournals.com/index.php/ijefi/article/view/7613/pdf

[37] Official Gazette RS (2010). Uredba o klasifikaciji delatnosti. Sluzbeni glasnik Republike Srbije, br. $54 / 2010$.

[38] Vatavu, S. (2015). The impact of capital structure on financial performance in Romanian listed companies. Procedia Economics and Finance, 32, 1314 - 1322. Retrieved from: https://core.ac.uk/download/pdf/82620497.pdf

[39] Vrzina, S. (2019). Corporate income tax and financial structure in transition countries: A case of the Republic of Serbia. Finansije, 1-6/2019, 37-52. Retrieved from: https://mfin.gov.rs/upload/media/2t0jjR_6017df516b80e.pdf

[40] Wahab, S. N. A., \& Ramli, N. A. (2014). The Determinants of Capital Structure: An Empirical Investigation of Malaysian Listed Government Linked Companies. International Journal of Economics and Financial Issues, 4(4), 930-945. Retrieved from: https://www.econjournals.com/index.php/ijefi/article/view/933/pdf

[41] Serbian Corporate Income Tax Law/Zakon o porezu na dobit pravnih lica. (2019). Sluzbeni glasnik Republike Srbije, br. 25/2001, 80/2002, 80/2002 - dr. zakon, 43/2003, 84/2004, 18/2010, 101/2011, 119/2012, 47/2013, 108/2013, 68/2014 - dr. zakon, 142/2014, 91/2015 - autenticno tumacenje, 112/2015, $113 / 2017,95 / 2018,86 / 2019$ i 153/2020.

Received: 2021-03-28

Revisions requested: 2021-06-14

Revised: 2021-08-09 (2 times)

Accepted: 2021-08-22

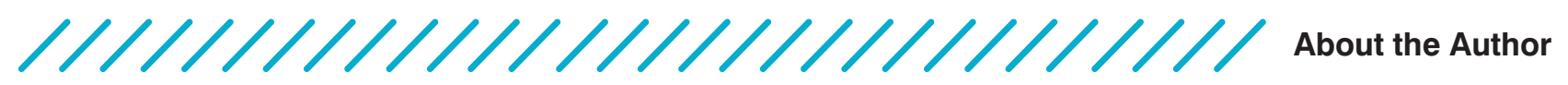

Teodora Tica

University of Novi Sad, Faculty of Economics, Subotica, Serbia and Ernst \& Young,

Belgrade, Serbia

teodoratica@gmail.com

Teodora Tica is currently a PhD candidate at Faculty of Economics in Subotica, the University of Novi Sad, in Corporate Finance, Accounting and Assurance. She received

a Bachelor's and Masters' Degrees in Finance, Banking and Insurance. Her field of scientific interest is tax area of corporate finance as well as theories of capital structure. She is a senior consultant in EY Belgrade Business Tax Advisory department. She has over three years of experience in tax advisory, audits, restructurings and due diligences

projects for various local and international clients operating in numerous industries.

Teodora's skills include transaction tax, corporate income tax, VAT, transfer pricing, tax incentives, tax structuring, etc.

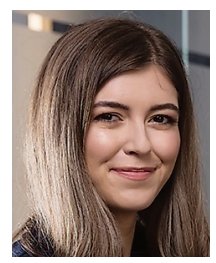

